DOI:10.22337/2587-9618-2018-14-3-136-141

\title{
BOLTS PULLING TEST. REVERSER FOR BOLTS TESTING
}

\author{
Mark P. Son \\ Perm National Research Polytechnic University, Perm, RUSSIA
}

\begin{abstract}
The article describes developed device for performing pulling tests of bolts, including high-strength. Principle of reverser operation is change of sign of applied load - compression of press causes stretching of a bolt. Advantages of presented reverser are: reliability, mobility, small size, economical operation and simpleness. Reverser designs permit to perform bolt tests at any hydraulic press. Using the developed device, deformation diagrams were obtained for bolts of different strength class 8.8 steel $40 \mathrm{Kh}$ and $20 \mathrm{G} 2 \mathrm{R}$ and 10.9 steel $40 \mathrm{Kh}$. These diagrams may serve as basis for numerical modeling of bolts in software packages, and also manual calculation of yielding. Tests revealed a number of advantages of bolts made of steel 20G2R over 40Kh, due to which application of bolts made of steel $20 \mathrm{G} 2 \mathrm{R}$ is recommended in assemblies of any level of responsibility.
\end{abstract}

Keywords: reverser, bolt,deformation diagrams,mechanical properties, yielding

\section{ИСПЫТАНИЕ БОЛТОВ НА РАСТЯЖЕНИЕ. РЕВЕРСОР ДЛЯ ИСПЫТАНИЯ БОЛТОВ}

\author{
М.П. Сон \\ Пермский национальный исследовательский политехнический университет, г. Пермь, РОССИЯ
}

\begin{abstract}
Аннотация: В статье описывается разработанное устройство для испытаний болтов, включая высокопрочные, на растяжение. Принцип работы реверсора заключается в смене знака прикладываемого усилия - сжатие пресса вызывает растяжение болта. К достоинствам представленного реверсора относятся: надежность, мобильность, компактность, экономичность и простота. Конструкция реверсора позволяет проводить испытания болтов на любом гидравлическом прессе. При помощи разработанного устройства были получены диаграммы деформирования для болтов класса прочности 8.8 сталей $40 \mathrm{X}$ и 20Г2Р и 10.9 стали 40Х. Данные диаграммы могут служить основой для численного моделирования болтов в программных комплексах, а также ручного расчета податливости. Испытания выявили ряд преимуществ болтов из стали 20Г2Р в сравнении с $40 \mathrm{X}$, в связи с чем, рекомендуется применение болтов из стали 20Г2Р в узлах любого уровня ответственности.
\end{abstract}

Ключевые слова: реверсор, болт, диаграммы деформирования, механические свойства, податливость

Bolt joints of beams and columns, high pressure vessels and other structures are critical components often determining reliability of the whole structure. To increase reliability of this type of joints it is necessary to apply design and calculation methods, based on consistent tests [7].

At present, there exists a large number of works dedicated to study of mechanical behavior of bolt and flange $\mathrm{s}$ joints, for example, study of operation of T-shaped flanges [6]. Article [1] presents variants of bolt joints of beams and columns. Work [2] presents results of series tests of full-scale samples. Sample consisting of column and adjacent beam was loaded with bending moment applied to beam until destruction of the joint, with varied plate size and number of connecting bolts. Study [3] shows that reinforcement of flange with additional stiffening ribs leads to increase of strength but decreases joint deformability. Share of plastic deformations in reinforced joint decreases and consequently decreases ability of the joint to disperse oscillations caused by seismic loads. Experimental and theoretical study of bolt joint "column - column" [4] 
performs detailed mathematic modeling of the assembly with regard to dimensional geometry of columns, flanges and bolts. Contact condition is given for flanges, implementing dry friction, preliminary tensioning of bolts is taken into account. Analysis of structure consisting of large number of bolted beams is given in work [5]. Structure behavior in case of exclusion of one bolt of flange joint is modeled.

Large number of studies are aimed to study bolt joints, while omitting the bolts themselves from the analysis. It is the bolt breakage which may constitute breakage of the assembly and the structure in whole. Calculations of bolt joints, of all mechanical bolt properties, use only design strength corresponding to strength class. In reality bolts of same strength class may be made of different steel grades, and consequently differ in relative elongation at failure and variation of mechanical properties.

Loads on assemblies and joints are mainly oscillatory. To increase fatigue strength bolts are pretensioned to value Fo. After application of external force $\mathrm{F}$ compression stress of joined flanges decreases and bolt receives additional force $\chi F$, and part of force equal to $(1-\chi) F$ decreases initial compression of flanges. Final loads in bolt and flanges may be determined according to formulas 1 .

$$
\begin{aligned}
& F_{b}=F_{o}+\chi F \\
& F_{f}=-F_{o}+(1-\chi) F
\end{aligned}
$$

where $F_{b}-$ full stress in bolt, $F_{f}$ - flanges compression stress, $\chi$ - main load factor.

Factor $\chi$, determining share of external stretching force additionally loading the bolt, is of special importance in calculation of joints operating under oscillatory loads. Main load factor depends on stiffness of flanges and bolt and may be found according to formula 2 :

$$
\chi=\lambda_{\mathrm{f}} /\left(\lambda_{\mathrm{b}}+\lambda_{\mathrm{f}}\right)
$$

where $\lambda_{b}-$ axial yield of bolt, $\lambda_{f}-$ axial yield of flanges (clamped parts).
In clamping flange package maximal compressing stresses are in points near opening under bolt head and nut. These stresses decrease to middle of the clamped package, forming cone of pressure (Figure 1). It is considered that base of cone does not depend on external load value and consequently compressed flanges operate as stem with cone-like section with opening until load reaches value $\mathrm{Fo} /(1-\chi)$ when flanges will open. Such model describes actual operation of thick thickness flanges with enough exactness. For thin (flexible flanges) calculation agrees with the experiments at large values of tightening stress $\sigma_{0}=(0,5-0,7) \sigma_{\mathrm{T}}$ and such external load which causes just slight opening of joint. Angle of inclination of cone generatrix is considered equal to $30^{\circ}$, consequently having calculated average cone diameter it is possible to obtain yield of flanges $\lambda_{\mathrm{f}}$.
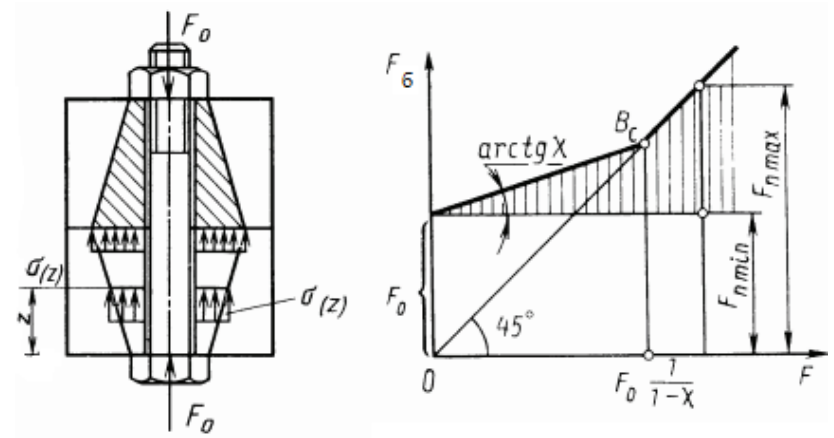

Figure 1. Distribution of stresses in compressed flanges over cone of pressure.

Yield of bolt may be determined as sum of yields pf its parts: cylindrical part of bolt and threaded part of bolt (where 1, A, E - length, area and elasticity modulus). Calculation of $\lambda_{b}$ is of no difficulties, but for short bolts $(1<6 \mathrm{~d})$ yield of bolt head $\left(\lambda_{\mathrm{h}}\right)$, and also of thread $\left(\lambda_{\mathrm{t}}\right)$ within limits of nut coupling should be considered. There are empiric formulas for calculation of $\lambda_{\mathrm{h}}$, $\lambda_{t}$, but as V.B. Kuklin has showed, yield of thread strongly depends on tolerance ranges and angle of profile of thread and nuts. Also V.B. Kuklin has found that contact deformations of operating surfaces of thread have significant influence on thread yield, which may 2-4 times surpass own yield of turns. 
Each bolt, following to GOST, should be marked with designation of strength class, which is determined according to results of bolt tests.

Bolts are testes at tensile testing machines equipped with special bolt grips. A bolt is «dressed» into an insert which is installed into a grip, which in turn is fastened to tensile machine rod.

2

1

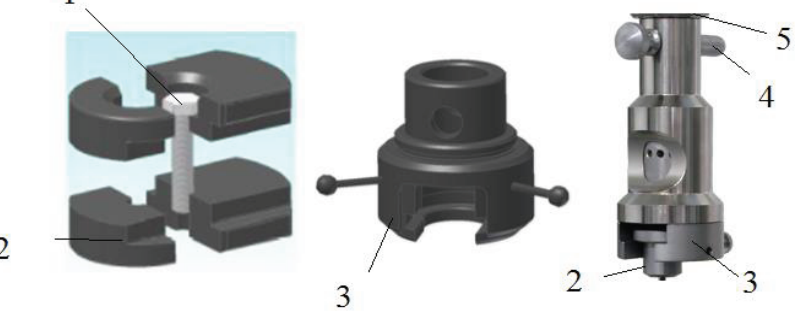

Figure 2. Attachment for testing bolts at tensile machine. 1 - bolt, 2 - inserts, 3 - grip, 4 - bush for fixing grip onto rod, 5 -rod of tensile machine.

Common main drawbacks for all types of these grips are:

1) High cost, grips for stretching bolts are not included into main kit of tensile machine and should be bought separately.

2) Possibility of using grips only in tensile machines made by same manufacturer.

3) Limited carrying capacity of grip. For example, grips for bolts Zwick/Roell for test machine line All round Line are limited to load of $250 \mathrm{kN}$, while temporary load on bolt may reach $2000 \mathrm{kN}$ (for bolts M48 strength class 12.9).

To eliminate the described drawbacks the author of this article has developed reverser for testing bolts. The device belongs to accessories for fixing and mechanical testing of bolts and highstrength bolts. Reverser consists of two same Ushaped metallic parts (Figure 3) with round opening in shelf of a part for bolt installation. Axis of opening coincides with axis of bolt and direction of stress. U-shaped parts are located orthogonally, connected with stands to each other until alignment of openings, after which connected by a bolt (high-strength bolt). Nut is screwed on threaded end of bolt. Connected parts are installed into a press. Compression of press makes them to spread, causing stretching stress on a bolt. So, principle of reverser operation is change of sign of applied stresses compression of press causes stretching of bolt.
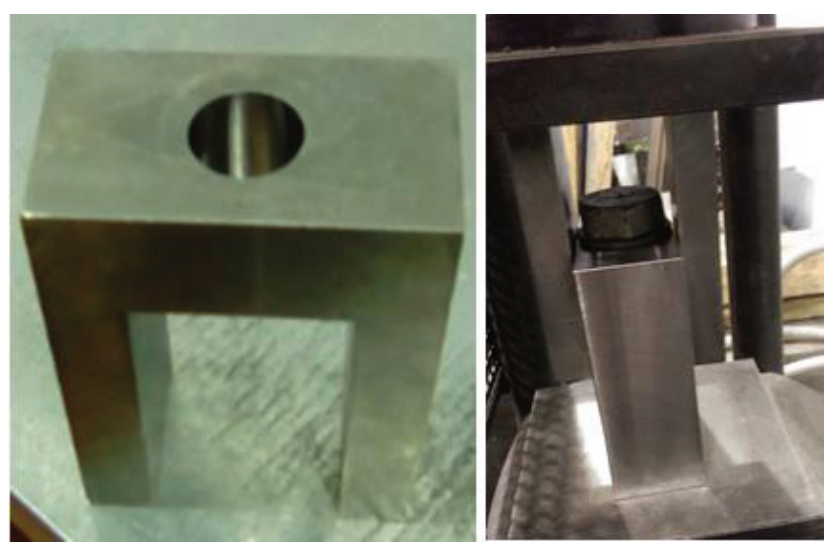

Figure 3. On the left-part of reverser, on the right - bolt test in press, using reverser.

Reverser compares favorably to grips, its main advantages are:

Universality - reverser may be installed and bolts testes at any press.

Reliability.

Mobility (transferability) is attained by small reverser weight.

Small size - reverser size is determined by diameter of bolts being tested.

Safety at break of bolt is achieved by the fact that bolt body is fully covered by the reverser itself (one U-shaped part from 2 sides, second part from 2 sides), which excludes possible shrapnel and bolt parts coming into personnel.

Economic operation - reverser is made from sheet metal using plasma cutting and has no expensive parts.

Simpleness - preparation process includes installation of bolt with turning on reverser, with following installation to press plate. Bolt is centered automatically, its preparation to test takes about 30 seconds.

Using this reverser, were tested bolts M24 from different steels, lots and strength classes. Tests were performed at hydraulic $500 \mathrm{t}$ press. Technical characteristics of press: load accuracy - $16 \mathrm{~kg}$, deformation accuracy - 0,0036 mm, 
loading speed $133 \mathrm{kN} / \mathrm{min}$. Bolt stretching diagrams were received (Figure 4-5).

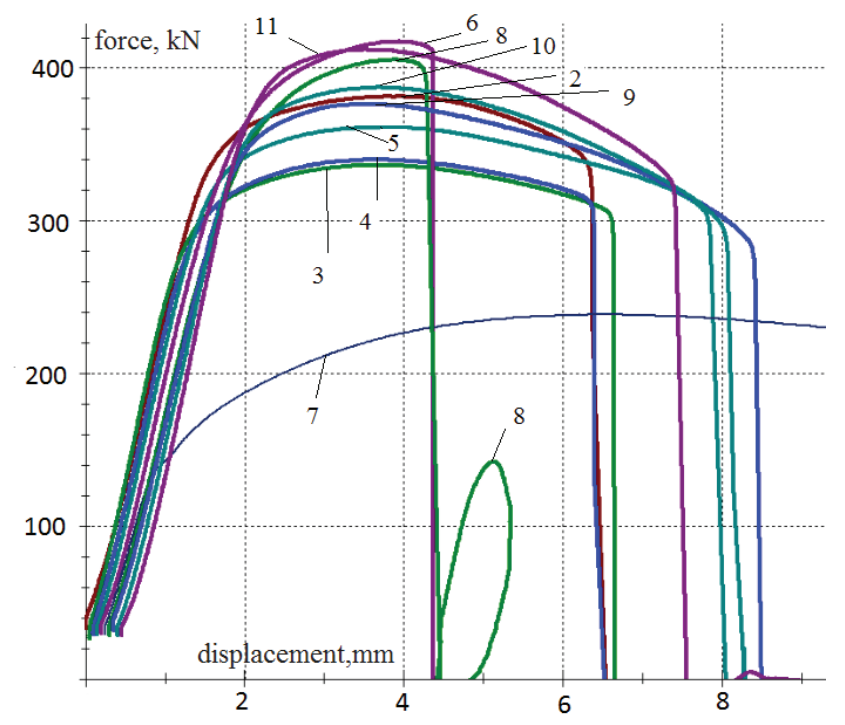

Figure 4. Diagrams of testing bolts of steel $40 \mathrm{Kh}$.

Diagrams 2-4 are built for bolts strength class 8.8 from steel $40 \mathrm{Kh}$. According to test results tensile strength of bolts was Rbun=950-1090 MPa.

Diagrams 5-11 are built for bolts strength class 10.9 from steel $40 \mathrm{Kh}$ «select». According to test results tensile strength of bolts was Rbun $=1040$ $1200 \mathrm{MPa}$, except for bolt № 7, which experienced maximal load $238,5 \mathrm{kN}(\sigma=676$ $\mathrm{MPa}$ ) and showed deformation diagram drastically different from other bolts, this product is considered defective. Also bolt № 8 may be considered defective, though it showed $\mathrm{R}_{\text {bun }}=1165 \mathrm{MPa}$, but destruction was by thread stripping, and according to GOST a test is considered satisfactory if breakdown happens in rod or free threaded part of bolt.

In other cases (tests 2-6, 9-11) destruction was brittle, bolts were broken at normal in threaded part by tearing off.

Also were tested bolts 8.8 from boron steel 20G2R. Deformation diagrams of 4 tested bolts (Figure 5) are practically identical. Maximal load on bolts was 339-343 kN, which corresponds to stresses $\sigma=960-970 \mathrm{MPa}$. Bolts showed greater plasticity comparing to bolts from steel $40 \mathrm{Kh}$. Destruction was ductile, with formation of sloping planes and characteristic tapering neck (Figure 6).
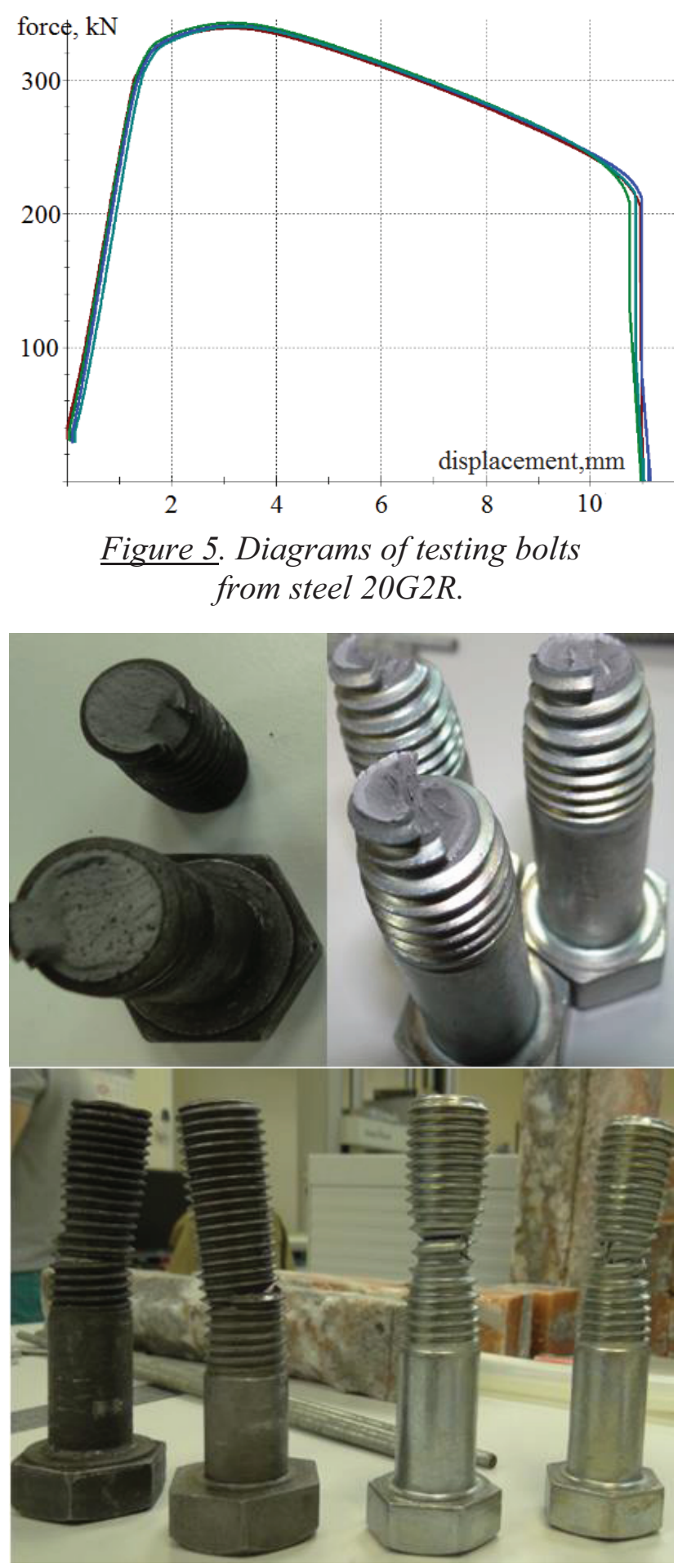

Figure 6. Characteristic destruction of bolts. On the left - bolts 10.9 from steel $40 \mathrm{Kh}$, on the right-bolts 8.8 from steel $20 G 2 R$. 


\section{CONCLUSION}

For calculation of bolt joints it is necessary to know actual diagrams of bolts operation, as their yield consists of yield of bolt body, yield of head and yield of thread. Using the developed device for mechanical stretch testing of bolts reverser, deformation diagrams for bolts strength class 8.8 steels $40 \mathrm{Kh}$ and $20 \mathrm{G} 2 \mathrm{R}$, and 10.9 steel $40 \mathrm{Kh}$ were obtained. These diagrams may serve as basis for numeric modeling of bolts in software packages, and also for calculation of share of main load according to formula 2. At present in Russia it is customary to design critical assemblies using bolts from steel $40 \mathrm{Kh}$, which is based on obsolete recommendations on design.Test revealed number of advantages of bolts from steel 20G2R comparing to $40 \mathrm{Kh}$. First, greater relative elongation at rupture.Second, smaller variation of mechanical properties. Also bolts 8.8 from steel 20G2R showed temporary resistance of 960-970 $\mathrm{MPa}$, which is higher than $800 \mathrm{MPa}$ assigned for the class, while bolts from steel $40 \mathrm{Kh}$ in some cases showed unacceptable strength or destruction scenario (in the thread) and were considered defective. So we recommend using bolts made of boron steel $20 \mathrm{G} 2 \mathrm{R}$ in assemblies of any level of responsibility.

\section{REFERENCES}

1. Ghindea M., Ballok R. State-of-the-art Review on Bolted Steel Beam-to-Column Connections // Bulletin of the Transilvania University of Braşov, 2015, Volume 8(57), Special Issue No. 1.

2. Prinz G.S., Nussbaumer A., Borges L., Khadka S. Experimental Testing and Simulation of Bolted Beam-column Connections Having Thick Extended Endplates and Multiple Bolts per Row. // Engineering Structures, 2014, 59, pp. 434447.
3. Abidelah A., Bouchair A., Kerdal D.E. Experimental and Analytical Behavior of Bolted End-Plate Connections with or Withour Stiffeners. // J Constr Steel Res, 2012, No. 76, pp. 13-27.

4. Liu X.C., He X.N., Wang H.X., Zhang A.L. Compression-Bend-Shearing Performance of Column-to-Column BoltedFlange Connections in Prefabricated MultiHigh-Rise Steel Structures.// Engineering Structures, 2018, Volume 160, pp. 439-460.

5. Blachowski B., Gutkowski W. Effect of Damaged Circular Flange-Bolted Connections on Behaviour of Tall Towers, Modelled by Multilevel Substructuring. // Engineering Structures, 2016, Volume 111, pp. 93-103.

6. Swanson J. Ultimate Strength Prying Models for Bolted T-stub Connections. // Engineering journal, Third quarter, 2002, pp. 136-147.

7. Baker M. Is There a Reproducibility crisis? // Nature, 2016, Volume 533, pp. 452-454.

\section{СПИСОК ЛИТЕРАТУРЫ}

1. Ghindea M., Ballok R. State-of-the-art Review on Bolted Steel Beam-to-Column Connections // Bulletin of the Transilvania University of Braşov, 2015, Volume 8(57), Special Issue No. 1.

2. Prinz G.S., Nussbaumer A., Borges L., Khadka S. Experimental Testing and Simulation of Bolted Beam-column Connections Having Thick Extended Endplates and Multiple Bolts per Row. // Engineering Structures, 2014, 59, pp. 434447.

3. Abidelah A., Bouchair A., Kerdal D.E. Experimental and Analytical Behavior of Bolted End-Plate Connections with or Withour Stiffeners. // J Constr Steel Res, 2012, No. 76, pp. 13-27.

4. Liu X.C., He X.N., Wang H.X., Zhang A.L. Compression-Bend-Shearing Performance of Column-to-Column Bolted- 
Flange Connections in Prefabricated MultiHigh-Rise Steel Structures.// Engineering Structures, 2018, Volume 160, pp. 439-460.

5. Blachowski B., Gutkowski W. Effect of Damaged Circular Flange-Bolted Connections on Behaviour of Tall Towers, Modelled by Multilevel Substructuring. // Engineering Structures, 2016, Volume 111, pp. 93-103.

6. Swanson J. Ultimate Strength Prying Models for Bolted T-stub Connections. // Engineering journal, Third quarter, 2002, pp. 136-147.

7. Baker M. Is There a Reproducibility crisis? // Nature, 2016, Volume 533, pp. 452-454.

Mark P. Son, Candidate of Technical Sciences, associate Professor, Department of Building structures and computational mechanics, Perm National Research Polytechnic University; 29-a, Komsomolsky prospect, Perm, 614600, Russia; fax: + 7(342) 2-453-440,

E-mail: mark-son.mail.ru.

Сон Марк Петрович, кандидат технических наук, доцент кафедры строительной механики и вычислительных технологий Пермского национального исследовательского политехнического университета; 614990, Россия, г. Пермь, Комсомольский пр., д. 29; факс: + 7(342) 2-453-440, E-mail: mark-son.mail.ru. 